Lewis, C. (1991). Nursery schools: The transition from home to school. In B. Finkelstein, A. Imamura, \& J. Tobin (Eds.), Transcending stereotypes -Discovering Japanese culture and education (pp. 81-95). Yarmouth, Maine: Intercultural Press.

Matsumoto, Y. S. (1960). Contemporary JapanThe individual and the group. Transactions of the American Philosophical Society, 50(1), 1-62.

Mizutani, O. (1992). Spoken language in Japanese life. Tokyo: The Japan Times Ltd.

Poole, G. S. (2010). Japanese professor: An ethnography of a university faculty. Rotterdam: Sense Publishers.
This essay first appeared in the newsletter of the Learner Development Special Interest Group of the Japan Association for Language Teaching. For this publication it was shortened and edited. 2012. Learning Learning, 19(3). Retrieved from $<$ ldsig.org/LL/19three/193toc.html>.

Caroline Ross teaches English at Nakamura Junior and Senior High School for Girls. Her interests include developing the concept of sustainable education.

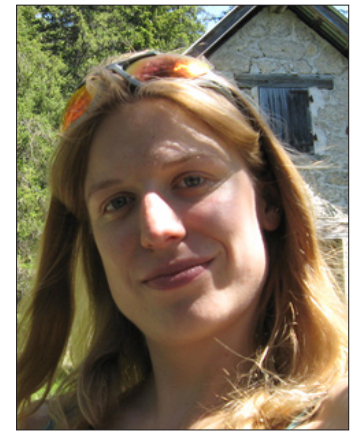

\title{
Autonomous learning: How can I help my students foster it?
}

\section{Yukiko Shimuzu}

\author{
St. Hilda's school, Tokyo
}

Japanese high school students are not usually given the opportunity to take charge of their own learning in large mixed level classes, but are required to take many exams while at the same time developing their English competence. This gives the students a negative attitude towards English. On the other hand, when they are placed in situations where they need to communicate with people from abroad, they use English as much as possible in order to make themselves understood. This paper describes such students' attitudes towards English and their learning environment and also considers ways to improve their autonomy.

日本の高校のクラスは一般に生徒数が多く、個々の能力にも開きがあ ると言われている。また、生徒自ら選択し学ぶ機会が十分に与えられて いるとは言い難く、いつも小テストや定期考査などの試験に追われてい るのが実情で、それが英語学習態度にもよくない影響を与えている。そ の一方で、英語を使って意思伝達を図りたいという姿勢は随所に見られ、 そこで得られた成功体験が前向きな学習態度につながっている。本論で は、そのような生徒の前向きな英語学習態度をどのようにクラスでの自 律的な英語学習に活かせるかについて考察する。

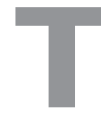

he English classes in my school are organised according to a curriculum and syllabus in order to help develop the students' language competence. Following the introduction of the new curriculum by the
Ministry of Education, Culture, Sports, Science and Technology in Japan (MEXT), the school syllabus has changed and new teaching methods and activities have been introduced in order to provide the students with more exposure to English in the classroom.

Traditionally, the Japanese English classroom is teacher-centered, each class normally consisting of 35 to 45 students of mixed competence. Teachers tend to be perplexed at how to deal with such groups and find these conditions taxing. Within a limited number of class periods, students are required to read English newspapers, books, and MEXT-authorized English course books, and also to increase their knowledge of grammatical rules and apply them to their practice of English conversation or essay writing. This may be why some students feel that it's difficult to keep up with the classes. They are also required to take numerous weekly mini-tests and term examinations, whose marks directly affect their grades. The results of these tests tend to influence the students' attitudes towards English. Those with poor results have negative attitudes towards English, asking why they have to study English even though they are Japanese and don't have to use English in their daily lives.

However, the students do like to use English when they communicate with people from over- 
seas. When I took some of the students to the tourist district of Asakusa in Tokyo to interview foreign tourists in English, all of them tried to make full use of what they had learned in their classes in order to communicate. This experience boosted their confidence and they realized that what they had learned in English classes was really meaningful. As a result of our trip, some of the students developed a more positive attitude towards English, some saying they intended to increase their contact with English pop culture and read books and newspapers.

Connecting such positive feelings of students to their current classes is something I would like to explore further. However, it is not a simple matter to construct these "perfect conditions" to improve students' motivation, as McCombs and Pope (1994) assume. Studies have shown that learners cannot foster autonomy in isolation, but need social interaction with a teacher and other learners in the classroom. Little (1999), has said that teachers should provide learners with group work, so lthey are able to gain motivation from frequently exchanging ideas with other group members. Dam (1999) has mentioned that the teacher's involvement produces powerful effects on learners taking responsibility for the whole process, from choosing their goals to assessing their own motivation. According to Ushioda (2012), it is beneficial to create an environment where learners can learn a language by means of interaction with the teacher and other learners and where they can be praised or encouraged by the teacher. Thinking of these studies in relation to my own classes, it may be necessary for me to create the kind of classroom environment where the students can socialize and shape their motivation, and where I can support and encourage the students wherever I can by giving them opportunities to take responsibility for their own learning. But are these measures really enough? What else do I have to do to improve my classes?

I have returned to graduate school to study English language teaching in more depth. Studying while working as a full-time teacher and taking care of two boys is quite challenging, but I find time to read, which broadens my horizons and enables me to look at my classes from different perspectives. As I read books on English language teaching and recall my 16 years of teaching at a private girl's school, I think it more necessary for teachers to help learners voluntarily study and utilize English outside the classroom. So I have become a member of the Learner Development SIG. I am very grateful that I have been given the opportunity to study learner development and to make improvements to my classes.

\section{References}

Dam, L. (1999). How to develop autonomy in a school context: How to get teachers to change their practice. In C. Edelhoff \& R. Weskamp (Eds.), Autonomes fremdsprachenlernen (pp. 113-133). Ismaning, Germany: Hueber.

Little, D. (1999). Autonomy in second language learning: Some theoretical perspectives and their practical implications. In C. Edelhoff \& R. Weskamp (Eds.), Autonomes fremdsprachenlernen (pp. 22-36). Ismaning, Germany: Hueber.

McCombs, B. L., \& Pope, J. E. (1994). Motivating hard to reach students. Washington, DC: American Psychological Association.

Ushioda, E. (24 March, 2012). Motivation and autonomy in language learning: Theoretical and pedagogical interactions (Open lecture). Tokyo: Temple University Japan.

This essay first appeared in Language Learning (Learner Development-Special Interest Group of the Japan Association for Language Teaching), 19(3), pp. 16-17. For this publication, it was shortened and edited.

Yukiko Shimizu has been teaching English at a private junior and senior high school in Tokyo for 16 years. She has an MA in linguistics and is currently studying English language teaching in more depth as a distance MA student at the University of Birmingham.

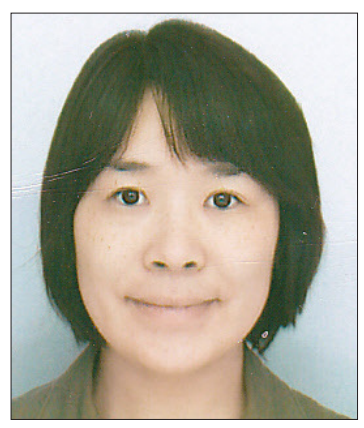

\section{On JALT20 I 2 Making a Difference}

The 2012 Conference Proceedings is now available to JALT members online!

Over 70 papers offering information and ideas to support and motivate you in your learning, teaching, and research. $<$ jalt-publications.org/proceedings $>$ 